\title{
Egg Traits and Physiological Neonatal Chick Parameters from Broiler Breeder at Different Ages
}

Author(s)

Luquetti $\mathrm{BC}^{1}$

Gonzales $E^{1}$

Bruno LDG

Furlan RL'

Macari $\mathrm{M}^{1}$

Centro Virtual de Pesquisa em Ciência Avícola Departamento de Morfologia e Fisiologia Animal, Faculdade de Ciências Agrárias e Veterinárias - Campus de Jaboticabal, Unesp, Jaboticabal, SP - Brazil

\section{Mail Address}

Marcos Macari

Departamento de Morfologia e Fisiologia Animal. Faculdade de Ciências Agrárias e Veterinárias

Campus de Jaboticabal - Unesp.

14.884-900 - Jaboticabal, SP, Brazil.

Telephone: 551632092656

Fax: $\quad 551632024275$

E-mail: macari@fcav.unesp.br

\section{Keywords}

Broiler breeder age, blood, cardiac, and lung parameters, neonatal chicks.

\section{ABSTRACT}

This investigation was carried out to study egg traits (weight, specific gravity and eggshell thickness), and neonatal chick parameters (weight, blood, cardiac and lung parameters) from breeder at different ages. After hatching, neonatal chicks, male and female, from broiler breeder at three different ages (30, 45 and 60 weeks) were sacrificed and blood (red blood cell number, hematocrit, mean cell volume, blood viscosity, and haemoglobin), cardiac (right ventricle and total ventricle weights, cardiac index) and lung (mean pulmonary pressure, fresh relative lung weight) parameters were measured. No significant differences in eggshell thickness or specific gravity were observed in eggs from the three different breeder age. The incubated eggs and neonatal chicks showed heavier absolute weights with increasing breeder age. Broiler breeder age did not affect blood parameters or cardiac index, but affected right ventricle and total ventricle absolute weights. Red blood cell number and hematocrit were higher and lung weight and lung weight:chick weight index were lower for female neonatal chicks. The findings of this study revealed that breeder age affects neonatal chick parameters such as body weight, heart and lung absolute weights, but not blood parameters.

\section{INTRODUCTION}

Several factors can affect the poultry egg characteristics, including hen age, environment, nutrition and genetics. It is well known that egg weight increases with hen age, reaching a plateau by the end of the laying cycle (Weatherup \& Foster, 1980). Hen age also affects the proportion of yolk, albumen and eggshell (Fletcher et al., 1981; Akbar et al., 1983; Danilov, 2000). The egg specific gravity and eggshell thickness decrease with advancing breeder age. This occurs basically because the egg size increases more quickly than the shell weight (Butcher et al., 1991) and because there is an increase in egg size rather than calcium deposition in the eggshell (Curtis et al., 1985).

There are many reports in the literature showing the influence of broiler breeder age on eggshell quality. However, the relationship between eggshell quality and the physiological parameters of embryos, especially those potentially involved in triggering metabolic diseases such as ascites or sudden death syndrome, has been poorly studied.

Several studies have attempted to relate broiler chicken susceptibility to ascites after hatching to anatomical or physiological parameters like right ventricle:total ventricle weight, hematocrit, thyroid hormones, and blood viscosity (Maxwell et al., 1986; Julian, 1987; Silversides et al., 1997; Gonzales et al., 1998; Nir, 1998); however, there is no report in the literature showing if in neonatal chicks these parameters are related to breeder age. Thus, the objective of this study was to investigate how 
Luquetti BC, Gonzales E, Bruno LDG, Furlan RL, Macari M breeder age (30, 45 and 60 weeks) affects eggshell characteristics and blood, cardiac and lung parameters of neonatal chicks.

\section{MATERIAL AND METHODS}

Six-hundred fertile eggs (200 per age) from three different breeder flocks (Cobb500 ${ }^{\circledR}$ ) aged 30, 45 and 60 weeks were obtained from a commercial hatchery. The eggs were individually weighed, identified, and incubated in a machine at $37.8{ }^{\circ} \mathrm{C}$ and $60 \%$ relative humidity, with the egg tray being turned once an hour through an angle of $90^{\circ}$ ( $45^{\circ}$ to each side). One day before hatching each egg was wrapped in an airpermeable sac (berloc). Approximately $2 \mathrm{~h}$ after hatching the chicks were separated by sex (feather sexed), and egg, blood, cardiac and lung parameters measured. This study was conducted in accordance with the Faculdade de Ciências Agrárias e Veterinárias Institutional Animal Care Committee.

Egg specific gravity and shell thickness were measured in 30 randomly chosen eggs per breeder age (30, 45 and 60 weeks). Egg specific gravity was determined by the method of Moreng \& Avens (1990), which involved placing the eggs in a series of saline solutions with increment of 0.005 units. For each egg, the shell thickness was determined at three different points in the middle part of the egg using a Mitutoyo caliper 7313 micrometer with $0.01 \mathrm{~mm}(0.01-10 \mathrm{~mm})$ precision.

Blood samples $(1.5 \mathrm{~mL})$ of all hatched chicks of each breeder age were collected by cardiac puncture using a sterile heparinized syringe after previous sedation of newly hatched chicks using sodium thiopental $(10 \mathrm{mg} /$ $\mathrm{kg} \mathrm{BW}$ ). After sampling, the chicks were sacrificed with a lethal dose of anesthetic (sodium pentobarbital, 50 $\mathrm{mg} / \mathrm{kg}$, i.v.), and the heart was collected and the atrium removed. Total ventricle (TV) weight was obtained, and the right ventricle (RV) was dissected and weighed using a precision balance $( \pm 0.001 \mathrm{~g})$. The cardiac index $(\mathrm{CI})$ was calculated according to the procedure described by Julian (1987) and Maxwell et al. (1992). Hematocrit $(\mathrm{Ht}, \%)$, red blood cell number $\left(\mathrm{RBC}, 10^{6} \mathrm{cells} / \mathrm{mm}^{3}\right)$, mean cell volume $\left(\mathrm{MCV}, \mu^{3}\right)$ and hemoglobin $(\mathrm{Hb}, \mathrm{g} /$ $\mathrm{dL}$ ) were determined using an automatic blood analyzer (Celm DA 500 ${ }^{\circledR}$ ). Blood viscosity was assessed with a Brookfield DV III $+{ }^{\circledR}$ viscosimeter using plane geometry, with spindle $S 42$ at $41{ }^{\circ} \mathrm{C}$, and speed of $250 \mathrm{rpm}$.

Mean pulmonary pressure (MPP) was calculated according to the formula proposed by Cueva et al. (1974), MPP $=-20.16+1.85 \mathrm{RV} / \mathrm{TV}$, where RV is right
Egg Traits and Physiological Neonatal Chick Parameters from Broiler Breeder at Different Ages

ventricle weight and TV is total ventricle weight, in grams, and MPP is expressed as $\mathrm{mmHg}$. The lungs were also collected, dried on Whatman filter paper and weighed to obtain the lung:chick weight ratio.

The experiment was performed in a 3 (breeders age - 30, 45 and 60 week) x 2 (sex) factorial arrangement according to a completely randomised design. Data were analysed statistically using the GLM procedure of the SAS program (SAS, 2000). Differences between means were determined by the Tukey test. The egg specific gravity and shell thickness data were subjected to an analysis of variance using the GLM procedure considering only the breeder age as effect.

\section{RESULTS}

\section{Egg parameters and neonatal chick weights}

The influence of broiler breeder age on eggshell thickness and egg specific gravity are summarized in Table 1. No significant differences in eggshell thickness or specific gravity were observed in eggs from the three different breeder age groups.

Table 1 - Means and analysis of variance for the effect of broiler breeder age on eggshell thickness and specific gravity. Each value represents the mean \pm SEM.

\begin{tabular}{|c|c|c|c|}
\hline & $\mathbf{N}^{1}$ & $\begin{array}{l}\text { Eggshell thick } \\
\text { ness (mm) }\end{array}$ & $\begin{array}{l}\text { Specific } \\
\text { gravity }\end{array}$ \\
\hline \multicolumn{4}{|c|}{ Breeder age (week) } \\
\hline 30 & 30 & $0.44 \pm 0.008$ & $1.085 \pm 0.001$ \\
\hline 45 & 30 & $0.44 \pm 0.007$ & $1.082 \pm 0.001$ \\
\hline 60 & 30 & $0.43 \pm 0.006$ & $1.082 \pm 0.001$ \\
\hline F value & & $1.69 \mathrm{~ns}$ & $1.75 \mathrm{~ns}$ \\
\hline
\end{tabular}

1 - Number of observations.

The data concerning egg weight, eggshell weight (absolute and relative), and chick neonatal weight (absolute and relative) are presented in Table 2. No interaction ( $p<0.05$ ) was observed between breeder age and sex for the data analysed. The incubated eggs increased in weight with increasing breeder age. The difference between 30-week vs 45-week, and 30-week vs 60-week groups for egg weight was more evident than between 45 -week vs 60-week groups. The same results were observed for the chick weights, with the relative weight being greater with younger hens. Thus, older breeders produced heavier chicks; however, the relative proportion of chick body weight was inversely related to breeder age.

Eggshell weight increased as the breeders became older. Nevertheless, the test of the means revealed that 
only the absolute eggshell weight of eggs from 30week-old-breeders was lighter than eggs from 45-week and 60-week-old breeders. Interestingly, the eggshell weight:egg weight ratio decreased in value with increasing breeder age. Thus, the youngest hens (30weeks) laid lighter eggs with lighter eggshells that produced lighter chicks. For egg and eggshell weights no sex effect was observed (Table 2).

\section{Blood, cardiac and lung parameters}

The blood parameters of neonatal chicks are shown in Table 3. Red blood cell number, hematocrit, mean cell volume, hemoglobin and blood viscosity of neonatal chicks were not affected $(p>0.05)$ by broiler breeder age. However, a significant effect of sex was observed, with male chicks having a lower $(p<0.05)$ number of red blood cells and a lower hematocrit than females.

The effects of breeder age and sex on cardiac and lung parameters are presented in Table 4 . Right ventricle weight (RV) and total ventricle (TV) plus septum weight were affected by breeder age, but not by sex ( $p>0.05$ ) or the interaction between age and sex. Chicks coming from eggs laid by 30-week-old breeders presented lighter RV and TV than those from 60-week-old ones, but no difference in chick cardiac index was observed between the three breeder groups. As a consequence, the mean pulmonary pressure of chicks from broiler breeders of different age was similar.

The calculated mean pulmonary pressure did not reveal pulmonary arterial hypertension in the chicks irrespective of broiler breeder age; however, absolute lung weight was dependent on breeder age, with chicks from older breeders having a heavier lung weight (Table 4). The data also revealed that the lung weight was heavy for male chicks from older hens. Although no significant ( $p>0.05)$ differences in lung weight:chick weight ratio among breeders groups of different ages were observed, male chicks presented a higher ratio than females (Table 4).

Table 2 - Means and analysis of variance for the effects of broiler breeder age (A) and chick sex (S) on egg weight before incubation, and eggshell and chicks absolute and relative weights after hatching. Each value represents the mean \pm SEM.

\begin{tabular}{|c|c|c|c|c|c|c|}
\hline & & Egg & & Eggshell & & Chicks \\
\hline & $\mathbf{N}^{1}$ & Weight, $g$ & Weight, g & Relative Weight, $\%^{2}$ & Weight, $\mathbf{g}$ & Relative Weight, $\%^{3}$ \\
\hline Breeder age & & & & & & \\
\hline 35 & 103 & $58.3 \pm 0.25 c$ & $5.82 \pm 0.07 b$ & $9.97 \pm 0.12 a$ & $42.2 \pm 0.24 c$ & $72.35 \pm 0.24$ \\
\hline 45 & 71 & $64.6 \pm 0.44 b$ & $6.14 \pm 0.11 a$ & $9.49 \pm 0.14 b$ & $46.0 \pm 0.44 b$ & $71.21 \pm 0.44$ \\
\hline 60 & 76 & $68.2 \pm 0.49 a$ & $6.07 \pm 0.09 a$ & $8.91 \pm 0.12 c$ & $48.6 \pm 0.48 a$ & $71.33 \pm 0.48$ \\
\hline Sex & & & & & & \\
\hline Male & 122 & $63.5 \pm 0.50$ & $6.02 \pm 0.07$ & $9.50 \pm 0.10$ & $45.7 \pm 0.39$ & $71.97 \pm 0.39$ \\
\hline Female & 128 & $62.7 \pm 0.48$ & $5.96 \pm 0.08$ & $9.51 \pm 0.12$ & $44.8 \pm 0.39$ & $71.47 \pm 0.39$ \\
\hline Fvalue & & & & & & \\
\hline Age (A) & & $195.40 *$ & $3.36^{*}$ & 19.10* & $76.56^{*}$ & $4.28^{*}$ \\
\hline $\operatorname{Sex}(S)$ & & $0.12 \mathrm{~ns}$ & $0.24 \mathrm{~ns}$ & $0.20 \mathrm{~ns}$ & $0.93 n s$ & $1.31 \mathrm{~ns}$ \\
\hline$A \times S$ & & $0.05 \mathrm{~ns}$ & $0.03 \mathrm{~ns}$ & $0.07 \mathrm{~ns}$ & $0.15 \mathrm{~ns}$ & $0.24 \mathrm{~ns}$ \\
\hline
\end{tabular}

Table 3 - Means and analysis of variance for the effects of breeder age (A) and chick sex (S) on blood parameters of neonatal chicks. Each value represents the mean \pm SEM.

\begin{tabular}{|c|c|c|c|c|c|c|c|}
\hline & \multirow[b]{2}{*}{$\mathbf{N}^{1}$} & \multicolumn{6}{|c|}{ Blood Parameters } \\
\hline & & $\begin{array}{l}\text { Red Blood Cells } \\
\left(\times 10^{6} \text { cells } / \mathrm{mm}^{3}\right)\end{array}$ & $\begin{array}{l}\text { Hematocrit } \\
(\%)\end{array}$ & $\begin{array}{c}\text { Mean Cell Volume } \\
\left(\mu^{3}\right)\end{array}$ & $\begin{array}{l}\text { Hemoglobin } \\
\text { (g/dL) }\end{array}$ & $\mathbf{N}^{1}$ & $\begin{array}{l}\text { Viscosity } \\
\text { (cP) }\end{array}$ \\
\hline \multicolumn{8}{|c|}{ Breeder age (week) } \\
\hline 30 & 102 & $2.48 \pm 0.03$ & $34.7 \pm 0.57$ & $140.4 \pm 1.39$ & $8.78 \pm 0.10$ & 38 & $0.26 \pm 0.009$ \\
\hline 45 & 70 & $2.49 \pm 0.04$ & $36.0 \pm 0.65$ & $145.3 \pm 1.87$ & $8.96 \pm 0.11$ & 35 & $0.25 \pm 0.008$ \\
\hline 60 & 73 & $2.44 \pm 0.05$ & $35.0 \pm 0.71$ & $143.8 \pm 1.85$ & $8.83 \pm 0.13$ & 33 & $0.27 \pm 0.006$ \\
\hline \multicolumn{8}{|l|}{ Sex } \\
\hline Male & 120 & $2.42 \pm 0.03 b$ & $34.5 \pm 0.49 b$ & $143.7 \pm 1.44$ & $8.73 \pm 0.10$ & 52 & $0.25 \pm 0.007$ \\
\hline Female & 125 & $2.52 \pm 0.03 a$ & $35.8 \pm 0.54 a$ & $142.0 \pm 1.30$ & $8.96 \pm 0.10$ & 54 & $0.26 \pm 0.006$ \\
\hline \multicolumn{8}{|l|}{ F value } \\
\hline Age (A) & & $0.28 n s$ & $0.10 \mathrm{~ns}$ & $1.64 \mathrm{~ns}$ & $0.39 \mathrm{~ns}$ & & $1.27 \mathrm{~ns}$ \\
\hline $\operatorname{Sex}(S)$ & & $6.05^{*}$ & $5.04 *$ & $1.23 \mathrm{~ns}$ & $3.48 \mathrm{~ns}$ & & $1.20 \mathrm{~ns}$ \\
\hline$A \times S$ & & $0.39 \mathrm{~ns}$ & $0.85 \mathrm{~ns}$ & $1.25 \mathrm{~ns}$ & $0.50 \mathrm{~ns}$ & & $0.34 \mathrm{~ns}$ \\
\hline
\end{tabular}




\begin{tabular}{|c|c|c|c|c|c|c|c|c|}
\hline & $\mathbf{N}^{1}$ & $\begin{array}{l}\text { Right Ventricle } \\
\text { (g) }\end{array}$ & $\begin{array}{l}\text { Total Ventricle } \\
\text { (g) }\end{array}$ & $\begin{array}{c}\text { Cardiac index } \\
(\%)\end{array}$ & $\mathrm{N}^{1}$ & $\begin{array}{c}\mathrm{MPP}^{3} \\
(\mathrm{mmHg})\end{array}$ & $\begin{array}{l}\text { Lung Weight } \\
\text { (g) }\end{array}$ & $\begin{array}{c}\text { LW:CW } \\
(\%)\end{array}$ \\
\hline \multicolumn{9}{|c|}{ Breeder age (week) } \\
\hline 30 & 95 & $0.046 \pm 0.001 b$ & $0.210 \pm 0.004 b$ & $22.06 \pm 0.40$ & 101 & $-19.74 \pm 0.01$ & $0.280 \pm 0.004 b$ & $0.666 \pm 0.010$ \\
\hline 45 & 54 & $0.048 \pm 0.001 \mathrm{ab}$ & $0.215 \pm 0.004 b$ & $22.30 \pm 0.52$ & 70 & $-19.72 \pm 0.01$ & $0.291 \pm 0.007 a b$ & $0.636 \pm 0.015$ \\
\hline 60 & 62 & $0.052 \pm 0.001 a$ & $0.232 \pm 0.006 a$ & $22.65 \pm 0.49$ & 75 & $-19.71 \pm 0.01$ & $0.303 \pm 0.007 a$ & $0.628 \pm 0.016$ \\
\hline \multicolumn{9}{|l|}{ Sex } \\
\hline Male & 105 & $0.048 \pm 0.001$ & $0.218 \pm 0.004$ & $22.10 \pm 0.36$ & 121 & $-19.73 \pm 0.01$ & $0.302 \pm 0.005 a$ & $0.664 \pm 0.01 a$ \\
\hline Female & 106 & $0.048 \pm 0.001$ & $0.217 \pm 0.004$ & $22.49 \pm 0.39$ & 125 & $-19.72 \pm 0.01$ & $0.279 \pm 0.006 b$ & $0.627 \pm 0.01 b$ \\
\hline \multicolumn{9}{|l|}{ Fvalue } \\
\hline Age $(A)$ & & $6.72^{*}$ & $6.29 *$ & $0.64 \mathrm{~ns}$ & & $2.25 \mathrm{~ns}$ & $3.64^{*}$ & $2.53 \mathrm{~ns}$ \\
\hline $\operatorname{Sex}(S)$ & & $0.66 \mathrm{~ns}$ & $0.019 \mathrm{~ns}$ & $0.92 \mathrm{~ns}$ & & $1.36 \mathrm{~ns}$ & $11.86^{*}$ & $7.30 *$ \\
\hline$A \times S$ & & $0.52 \mathrm{~ns}$ & $0.18 \mathrm{~ns}$ & $0.54 \mathrm{~ns}$ & & $0.05 \mathrm{~ns}$ & $1.62 \mathrm{~ns}$ & $1.26 \mathrm{~ns}$ \\
\hline
\end{tabular}

\section{DISCUSSION}

The eggshell quality is an important factor to poultry industry due to reproductive and economic implications. However, eggshell quality is related with bird age (Peebles \& Brake, 1987). McDaniel et al. (1979) observed a decline in specific gravity in older breeders and Garlich et al. (1984) verified a decrease in shell thickness during the course of the first laying year. In the present study, although the egg weight increased and proportional eggshell deposition decreased significantly with breeder age, no significant differences were observed in specific gravity of eggs or eggshell thickness from older breeders. The differences found between results may be partially attributable to differences in lines, nutrition and sample period, which are also related to shell quality.

The difference in chick weight at hatching is due to egg size, since Wiley (1950) proposed that egg volume is a limiting factor to embryo development. As shown by Hassan \& Nordskog (1971), the most striking relationship between egg weight and embryo growth was seen at 16 days of incubation and at hatching, irrespective of breeder age. Our findings showed that neonatal chick weight was dependent on broiler breeder age, supporting the hypothesis of Wiley (1950), since the older the breeder, the bigger the egg.

The blood parameters of neonatal chicks were not affected by broiler breeder age, but red blood cell number and hematocrit were lower in males than in females. These findings suggest that, irrespective of breeder age, the blood capability to transport oxygen and related metabolic substrates was similar in all chicks despite the difference in body weight. A sex difference had been reported during embryo development in broiler chicks (Mitchell \& Burke, 1995) and turkey chicks (Burke et al., 1994), especially related to hormone concentration; however, no data were found in the literature regarding blood parameters in the embryo due to breeder age.

Other blood parameter studied in broiler chickens was blood viscosity. High hematocrit values have been recognised as one of the conditions that increase blood viscosity (Maxwell et al., 1992). Our results showed that red blood cell number and hematocrit value were affected by broiler chick sex, but did not affect blood viscosity. These findings may indicate that hematocrit value cannot be used to support the total change in blood viscosity. The results provide no evidence that breeder age affects blood viscosity.

Hypertrophy of the right ventricular wall can be directly related to increased pulmonary arterial pressure, and the ratio of the right ventricle to the total ventricle mass can be used as a measurement of the increased pressure load on the right ventricle (Burton et al., 1968; Julian et al., 1986). In this study, absolute right ventricle and total ventricle weights, as expected, were affected by breeder age but, the cardiac index was not, and sex had no effect on these heart parameters. Thus, these findings revealed that ventricle development follows a normal growth during embryogenesis, and that breeder age and sex are not determining factors that could influence right ventricle or total ventricle weights until hatching. These results suggest that chick susceptibility to metabolic diseases after hatching seems not to be related to breeder age. 
In conclusion, the findings of this study revealed that broiler breeder age affects the characteristics of neonatal chicks, such as live body weight and absolute heart and lung weight, but blood parameters (viscosity, red blood cell number, hematocrit, mean cell volume and hemoglobin) and the eggshell characteristics are not dependent on breeder age.

\section{REFERENCES}

Akbar MK, Gavora JS, Friars GW, Gowe RS. Composition of eggs by commercial size categories: effects of genetic group, age and diet. Poultry Science 1983; 62:925-933.

Burke WH, Shultz FT, Bielfelt SW. The role of plasma growth hormone, prolactin, triiodothyronine and tetraiodothyronine in the regulation of growth and sex differences in body weight of turkeys. Growth Developing and Aging 1994; 58:167-185.

Burton RR, Besch EL, Smith AH. Effect of chronic hypoxia on the pulmonary arterial blood pressure of the chicken. American Journal Physiology 1968; 214:1438-1442.

Butcher G, Miles R, Nilipour A. La calidad del cascarón del huevo. Industria. Avicola 1991; 38:9-10.

Cueva S, Sillau H, Valenzuela A, Ploog H. High altitude induced pulmonary hypertension and right heart failure in broiler chickens. Research Veterinary Science 1974; 16:370-374.

Curtis PA, Garder FA, Mellor DB. A comparison of selected quality and compositional characteristics of brown and white shell eggs. I. Shell quality. Poultry Science 1985; 64:297-301.

Danilov RV. Effect of hen's age on quality of hatching eggs and embryonic development. Proceedings of 21 th World's Poultry Congress 2000; Montreal, Canada. CD-ROM (WPSA).

Fletcher DL, Britton WM, Rahn AP, Savage SI. The influence of layer flock age on egg components yields and solid content. Poultry Science 1981; 59:983-987.

Garlich J, Brake J, Parkhust CR, Thaxton JP, Morgan GW. Physiological profile of caged layers during one production year, molt, and postmolt. Egg production, eggshell quality, liver, femur, and blood parameters. Poultry Science 1984; 63:339-343.

Gonzales E, Buyse J, Takita TS, Sartori JR, Decuypere E. Metabolic disturbances in male broilers of different strains. I Performance, mortality, and right ventricular hypertrophy. Poultry Science 1998; 77:646-1653

Hassan EM, Nordskog AW. Effect of egg size and heterosis on embryonic growth and hatching speed. Genetic 1971; 67:279285.
Julian RJ. The effect of increased sodium in the drinking water on right ventricular hypertrophy, right ventricular failure and ascites in broiler chickens. Avian Pathology 1987; 16:61-71.

Julian RJ, Summer J, Wilson JB. Right ventricular failure and ascites in broiler chickens caused by phosphorus-deficient diets. Avian Disease 1986; 30:453-459.

Maxwell MH, Robertson GW, McCorquodale CC. Whole blood and plasma viscosity values in normal and ascitic broiler chickens. British Poultry Science 1992; 33:871-877.

Maxwell MH, Robertson GW, Spence S. Studies of ascitic syndrome in young broilers. I. Hematology and pathology. Avian Pathology $1986 ; 15: 515-524$

McDaniel GR, Roland DA, Coleman MA. The effect on eggshell quality on hatchability and embryonic mortality. Poultry Science 1979; 58:10-13.

Mitchell RD, Burke WH. Genotype and sexual influences on growth and muscle development of chicken embryos. Growth Developing and Aging 1995; 59:31-44.

Moreng RE, Avens JS. Ciência e produção de aves. São Paulo: Roca, 1990. 380p

Nir I. Interaction of genetic stocks, growth rate, feeding regime and metabolic diseases. Proceedings of 10th European Poultry Conference 1998; Jerusalem, Israel, pp.105-112 (WPSA).

Peebles ED, Brake J. Eggshell quality and hatchability in broiler breeders eggs. Poultry Science 1987; 66:596-604.

SAS Institute. SAS ${ }^{\circledR}$ (Statistical Analysis System). User's guide:Statistics. SAS Institute Inc., Cary, NC; 2000.

Silversides FG, Lefrançois MR, Villeneuve P. The effect of strain of broiler on physiological parameters associated with the ascites syndrome. Poultry Science 1997; 76:663-667.

Weatherup STC, Foster WH. A description of the curve relating egg weight and age of hen. British Poultry Science 1980; 21:511 519.

Wiley, WH The influence of egg weight on the pre-hatching and post-hatching growth rate in the fowl. II. Egg weight:chick weight ratios. Poultry Science 1950; 29:595-604. 